\title{
Behavior of Cantilever Beams in R.C. Frames with Effect of Steel Fibers in Beam - Column Joint
}

\author{
Mohanad Salih Farhan \\ Department of Civil Engineering, College of Engineering, University of Al-Mustansiriayah \\ j_shwik@yahoo.com
}

\begin{abstract}
This paper aims at investigating the behavior of cantilever beam in reinforced concrete frame modified by steel fibers. The study depends on adding steel fibers at the joint of beam column section to improves the ductility of the beam - column joint. Steel fibers of ratio $(0.5 \%)$ and $(1 \%)$ steel fibers by volume added for two specimens comparing with two others cast without steel fibers joint in R.C. frame. The cantilever frame behavior at applied load will be discussed in this study. The load applied to the frame at the edge of cantilever arms. The test results showed that the difference between the monolithic frame is larger in ultimate loads compared with nonmonolithic, and the frame with $1 \%$ steel fibers have large load capacity compared with $0.5 \%$ steel fibers frame. The frame which cast monolithically shows highest resistance among the three other frames in ultimate load and flexural deformation, after load was applied to the four specimens the behavior of the frame up to the failure occurred in the beam-column joint at exterior face of the cantilever. beside studying the effect of steel fibers percentage and behavior of beam column joint, this study focuses also on investigating the difference between monolithic and non-monolithic concrete elements.
\end{abstract}

Keywords: frame, steel fiber, SFRC, cantilever frame, beam column joint., monolithic, non-monolithic.

Paper History: (Received: 18/10/2016; Accepted: 29/5/2017)

\section{Introduction}

The beam - column joint has limited amount of strength capacity because this capacity is determined by its strength. When the applied load is greater than the nominal strength capacity of the joint, the connection between the structural elements fails. The flawed in this model must be avoided, and the repair of this type of failure is rather complicated. More important, the design of beam - column section should be considered in the design in order to reduce the overload effects [1].

So as to improve the ductility behavior of beam-column joint, shear reinforcement could be added in small percentage to the structural member. In the meantime, the workability of concrete for this area should be considered. In order to overcome the difficulties of using extra percentage of stirrups in narrow sections, GENCOGLU and EREN in 2002, used steel fibers in intersection of the beam - column area and the specimens were subjected to reversed cyclic load. The results of strength energy capacity and failure pattern were discussed in that study. Additionally, the same author studied the behavior of the beam column joint subjected to cyclic load in fullscale frame model. The results showed an increment in the ductility with strength capacity, when the steel fibers were used. The steel fibers can reduce the percentage of the stirrups at the intersection zone. The percentage of steel fibers, steel fiber type, and the area of structure where the steel fibers used, are all effect the ductility, and strength capacity [2].

Another study reinforced concrete structure by using ultra-high steel fibers to strengthening the connection between beam - column was done by WANG and LEE in 2007. Then, the joint was subjected to cyclic load in order to assess the joint behavior under the effect of seismic load. The results showed that the use of ultra-high strength steel fibers in concrete improved the performance of the joint remarkably. The mechanical properties for this type of fibers gave better results in compressive strength, bond, flexural and shear. The behavior of joint under seismic load was highly reasonable. Moreover, the behaviors were even better when reinforced concrete jacketing was used added [3].

\section{Product Materials and Method}

Ordinary Portland cement was used throughout this investigation. Chemical and physical properties of the cement are listed in Tables 1 and 2, respectively. The cement complies with the Iraqi Specification No. 5/1984 [14].

Natural fine aggregate of maximum size 4.75 $\mathrm{mm}$ was used as fine aggregate. In Table 3 the sieve analysis of the sand is shown, while its chemical and physical properties are shown in 
Table 4. Test Results show that the sand grading and sulfate content are within the limits of Iraqi Specification No. 45/1984 [15]. Crushed coarse aggregate with specific gravity of 2.62 is used. Table 5 illustrates the sieve analysis of the coarse aggregates which complies with Iraqi Specification No. 45/1984[15].

Table 1 Chemical Composition of Used Cement.

\begin{tabular}{|c|c|c|c|}
\hline 0xide Composition & Abbreviation & Content (\%) & Limit of (L.0.S.)N $\mathrm{N}_{0.5 / 1984}$ \\
\hline Lime & $\mathrm{CaO}$ & 63.19 & $\ldots$ \\
\hline Silica & $\mathrm{SiO} 2$ & 20.60 & $\ldots$ \\
\hline Alumina & AL203 & 4.10 & $\ldots$ \\
\hline Iron Oxide & $\mathrm{Fe} 203$ & 4.48 & $\ldots$ \\
\hline Sulphate & $\mathrm{SO3}$ & 1.98 & $<2.8 \%$ \\
\hline Magnesia & $\mathrm{Mg} 0$ & 2.28 & $\leq 5 \%$ \\
\hline Loss on Ignition & L.0.I & 2.45 & $\leq 4 \%$ \\
\hline Insoluble Residue & I.R & 0.47 & $\leq 1.5 \%$ \\
\hline Lime Saturation Factor & L.S.F & 0.94 & $0.66-1.02 \%$ \\
\hline \multicolumn{4}{|c|}{ Main Compounds (Bogue's Equations) } \\
\hline Tricalcum Silicate & C3S & 57.11 & \\
\hline Dicalcum Silicate & C2S & 16.23 & \\
\hline Tricalcium Aluminate & $\mathrm{C} 3 \mathrm{~A}$ & 8.39 & $>5 \%$ \\
\hline Tetracalcum Alumina Ferrite & CAAF & 13.62 & \\
\hline
\end{tabular}

Table 2 Physical Properties of the Used Cement.

\begin{tabular}{|c|c|c|}
\hline Physical Properties & Test Results & $\begin{array}{c}\text { Limit of (L.0.S.) } \\
\text { No.5/1984 }\end{array}$ \\
\hline Specific Surface area (Blaine Method, cm/gm) & 3329.0 & $\geq 2300.0$ \\
\hline Setting time (Vicat's Method) & & \\
Initial Setting time (hrs.: min) & $2: 10$ & $\geq 1: 00$ \\
Final Setting time (hrs.: min) & $3: 45$ & $\leq 10: 00$ \\
\hline Compressive strength of mortar & & \\
3-days (NPa) & 32.4 & $\geq 15$ \\
7-days (MPa) & 40.5 & $\geq 23$ \\
\hline
\end{tabular}

Table 3 Grading of Sand.

\begin{tabular}{|c|c|c|}
\hline $\begin{array}{c}\text { Siere Size } \\
(\mathrm{mm})\end{array}$ & $\begin{array}{c}\text { Cumulative Pasing } \\
(\%)\end{array}$ & $\begin{array}{c}\text { Limits of (LO.S.). Yo.45/1984, Zone (3) } \\
\text { Cumulative Pasing (\%) }\end{array}$ \\
\hline 4.75 & 100 & $90 \cdot 100$ \\
\hline 2.36 & 92.1 & $85 \cdot 100$ \\
\hline 1.18 & 82.0 & $75 \cdot 100$ \\
\hline 0.60 & 66.3 & $60 \cdot-79$ \\
\hline 0.30 & 29.5 & $12-40$ \\
\hline 0.15 & 8.5 & 0.10 \\
\hline
\end{tabular}

Table 4 Physical and Chemical Properties of Sand.

\begin{tabular}{|c|c|c|}
\hline Properties & Test Results & Limit of (LO.S.). No.451984 \\
\hline Specific Gravity & 2.60 & $\cdot$ \\
\hline Absorption \% & 0.75 & $\cdot$ \\
\hline Sulfate Content as SO3\% & 0.08 & $\leq 0.5$ \\
\hline
\end{tabular}

Table 5 Grading of Coarse Aggregate.

\begin{tabular}{|c|c|c|}
\hline $\begin{array}{c}\text { Sieve Size } \\
(\mathrm{mm})\end{array}$ & $\begin{array}{c}\text { Cumulative Passing } \\
(\%)\end{array}$ & $\begin{array}{c}\text { Limit of Iraqi Specification No. 45/1984 } \\
\text { Cumulative Passing (\%) }\end{array}$ \\
\hline 14 & 100 & 100 \\
\hline 10 & 98.9 & $85-100$ \\
\hline 5 & 17.4 & 0.25 \\
\hline 2.36 & 0.5 & 0.5 \\
\hline
\end{tabular}

\section{Experimental Program}

The experimental study of two exterior beamcolumn joint namely control (C), and the other three specimens named $(\mathrm{C} 1, \mathrm{C} 2, \mathrm{C} 3)$ respectively. The specimens were cast and tested of four reinforced concrete frame (beamcolumn joint) with the dimensions (1400x1000x200) mm, as shown in Figure (1.a and 1.b). Using concrete mix with an average cube compressive strength (fcu) equal to (30 $\mathrm{MPa})$. All frame specimens have the same dimension and the concrete cover satisfied to the ACI-318 (40) $\mathrm{mm}$. The variable which were investigated in this study include (the effect of steel fiber on mix design, beam column joint interfere, monolithically, nonmonolithically).

Wooden molds were used for casting reinforced concrete frame specimens, they were made according to the specific dimension for study needs with dimension (1400x1000x200) mm Figure (2a. and 2b.).

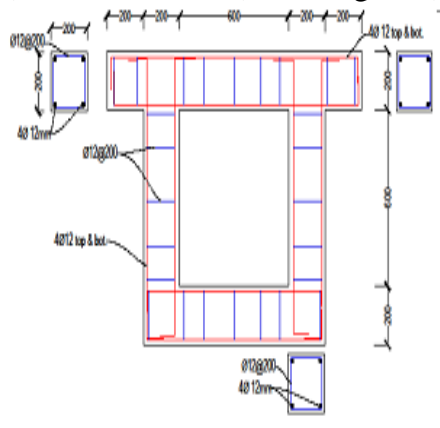

a) Reinforcement details

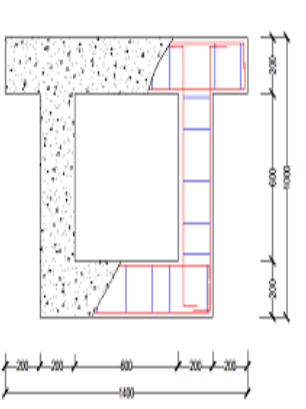

b) Frame Details
Figure 1: Details of Frame Specimen and its Loading Arrangement

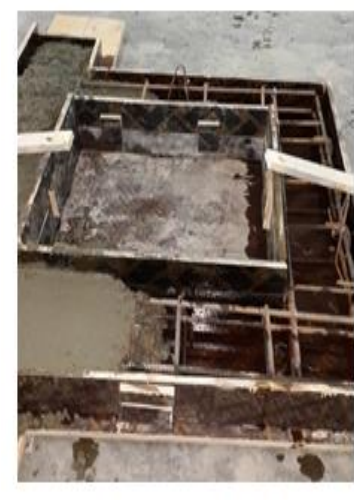

Figure 2-a: details of Mold

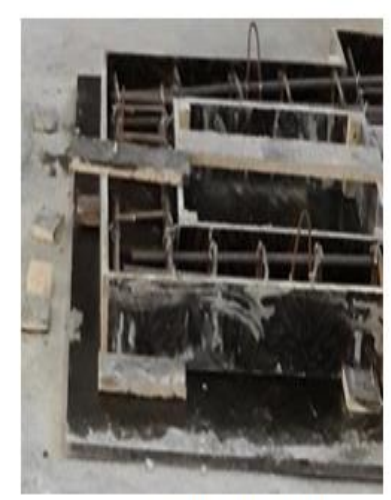

Figure 2-b: details of Mold
Figure 2: details of mold

\section{Laboratory work procedure}

All materials were weighted and stored in clean storage. Dry crushed coarse aggregate and surfaces saturation and dry clean fine aggregate added to the rotary drum mixer with volume capacity about $(0.18 \mathrm{~m} 3)$ and mixed for several minutes. The cement added as part of 
mix design to the mixer after coarse and fine aggregate were well mixed. The water was added gradually to the mix. The whole operation will take about (9-11 minutes) to complete mix and prepare to cast action. To avoid the adhesion with mold faces brush have used to paint the molds with light layer of oil before laying the reinforcement bars in molds. Before casting the concrete mix in the molds, steel reinforcement bars were placed in the mold with the consideration to concrete cover and lift the reinforcement from the mold according to ACI-318 code requirements for spacing. The frames were casted in three layers. The time required to compact the mixes was about (1.5-2 minutes) for each layer using vibration table with a compaction, as in Figure 3. After that, the frame specimens were covered by sheets, and after 24 hours the hardened models were removed from molds and placed in final curing for 27 days.
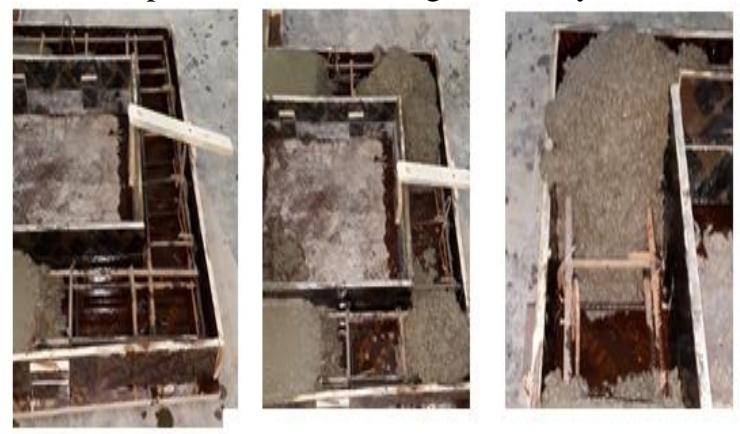

Figure 3: Casting Procedure

Tools measurement Testing and equipment instrumentation

The universal testing machine was used to test the frame specimens. All specimens were tested in structural laboratory; the deflection was measured by dial gauge of $(0.01 \mathrm{~mm})$ accuracy. two dial gauges placed with $(30 \mathrm{~mm})$ total grade. The dial gauges were mounted at the edge of cantilever at the bottom face of the frame and the other one was mounted in the midspan of frame. Figure (1.c.) shows the test preparation with tools and machines. The frame tests were done at the structures laboratory. in Al-Mustansiriayah University, Faculty of Engineering. Figure 4.

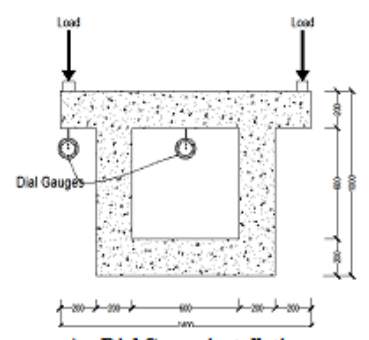

c) Dial Gauge installation

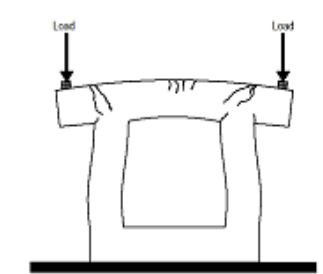

d) Imaginary deflection behavior
Figure 1: Details of Frame Specimen and its Loading Arrangement
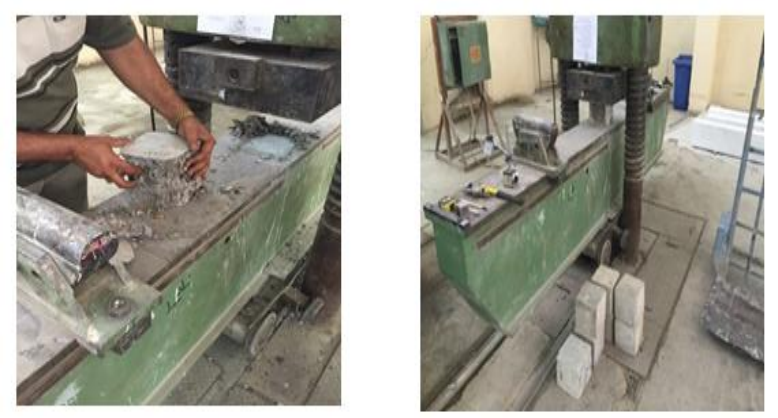

Figure 4: Test Instruments

\section{Results and Discussion}

\section{General}

In this investigation full-scale, four R.C. frame samples were tested. These frames were similar in dimensions (length, width, thickness), and steel reinforcement ratio, but different in concrete density and joint connection. The ultimate loads and crack patterns of different failure modes were various according to each individual sample

\section{Ultimate and first crack loads, and crack configuration}

The cracking test results and the ultimate loads are shown in Table 6 . At the time when the load was applied to these samples. The first cracks recorded at load about (20.3-32.6) \% in the range of the ultimate load for all frames.

The failure was usually observed in the tension zone at the beam-column joint connection, and was featuring by yielding the steel reinforcement in the tension zone, followed by crushing of concrete in compression face of joint with wide clear crack at the top face.

When the frame was casted as monolithically beam-column joint connection, large wide opening cracks were observed at the connection joint in the upper edge and small hairy cracks at the midspan at top face of frame.

When the frame was cast with steel fibers (0.51) $\%$ by weight, the flexural cracks at the joint connection at midspan were insignificantly. However, the cracks appeared due to flexural quite widely due to flexural effect severely after yielding point of steel reinforcement along with the failure in concrete of compression zone.
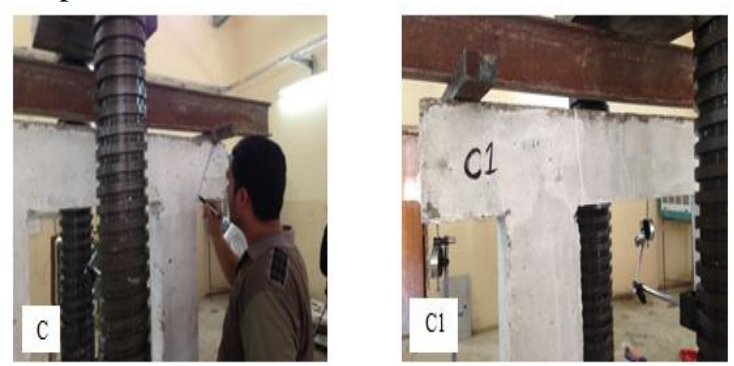

Figure 5: Crack Patterns 

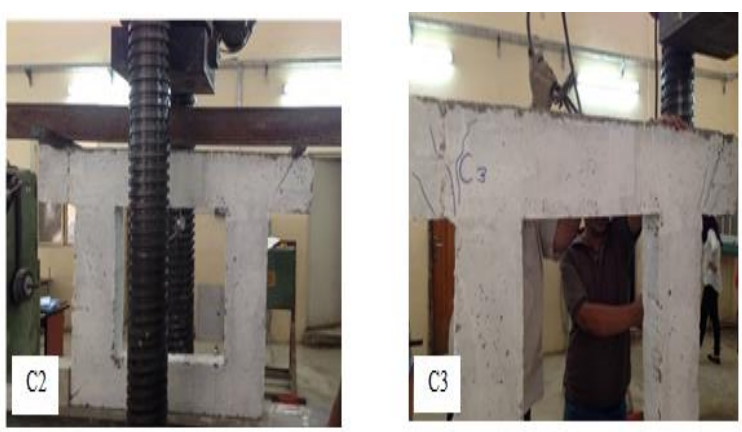

Figure 6: Crack Patterns

Table 6 First Crack and Ultimate Loads of Frames.

\begin{tabular}{|c|c|c|c|c|c|c|}
\hline specimen & Description & Dimession (mm) & $f_{w\left(B_{2}\right)}$ & $\begin{array}{c}\text { Fistcrack bosd } \\
\left(P_{w}\right)(k-1)\end{array}$ & $\begin{array}{c}\text { Climste } \\
\text { lood } \\
\left(P_{d}\right)(k V)\end{array}$ & $P_{v e} P_{v}\left(Y_{i}\right)$ \\
\hline$c$ & Non-Monolithically & $1400 \times 1000 \times 200$ & 30 & 29.35 & 112.3 & 26.13 \\
\hline C1 & Monolithically & $1400 \times 1000 \times 200$ & 30 & 80.21 & 245.1 & 32,65 \\
\hline C2 & $0.5 \%$ steel fiber & $1400 \times 1000 \times 200$ & 30 & 54.82 & 233.2 & 23.51 \\
\hline$C 3$ & $1 \%$ steel fiber & $1400 \times 1000 \times 200$ & 30 & 42,50 & 209.4 & 20,33 \\
\hline
\end{tabular}

\section{Ultimate loads}

The ultimate loads of test results for the frames cast without steel fibers and monolithic (C1) in beam-column joint area was greater than the frames casted with steel fibers $(\mathrm{C} 2, \mathrm{C} 3)$. The ultimate loads percentage increase (4.814.7)\%, respectively .see Figure 7 . The frame (C) and (C1) show that the ultimate loads were decrease when the frame casted Nonmonolithically than the frame which cast monolithically, and the amount of the ultimate load decrease about (54)\%, See Figures 8 and 9. The ultimate loads for the frames ( $\mathrm{C} 2$ and C3) indicate that the amount of steel fiber $(0.5) \%$ when added to the concrete mix for frame $(\mathrm{C} 2)$ are less than the ultimate load for frame with $1 \%$ of steel fibers (C3) about (10.3)\%, see Figure 7.

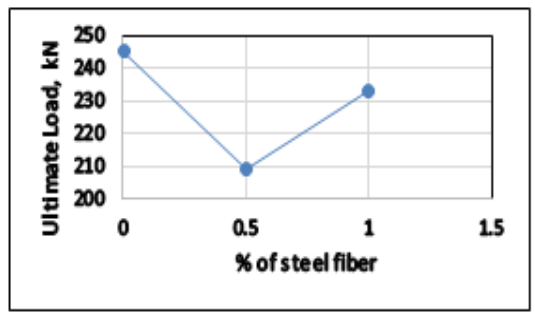

Figure 7: Ultimate Load $-\%$ of S.F

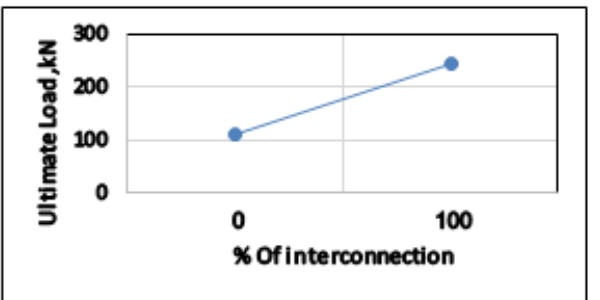

Figure 8: Ultimate Load - \%of Interconnection

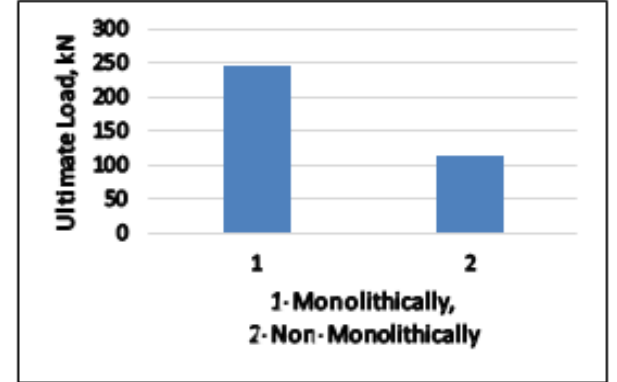

Figure 9: Ultimate Load - Monolithic \& nonmonolithic

\section{Load-displacement behavior and load capacity}

The results of deflection for specimens are illustrated in Table 7. The test results showed that for frame $(\mathrm{C} 2)$ the maximum deflection at ultimate load occurs when the frame concrete strengthened by $0.5 \%$ steel fibers. The maximum deflection at ultimate load decreased when the percentage of steel fiber increased to (1) \% by volume for the frame (C3), The maximum deflection at ultimate load for the Non-Monolithic frame cast (C) was resulted as small amount of maximum ultimate load and minimum load-deflection, comparing with the Monolithic frame cast $(\mathrm{C} 1)$ beam-column joint connection. The difference between the two frames about (54) \% in ultimate load. The deflection between them was about (25.17) \% . For general visualization, the maximum loaddeflection for specimen (C1) indicates the larger amount for load capacity and maximum deflection ultimate load. As given in Figure 10.

Table 7 Load - displacement Characteristics at Ultimate Loads and First Crack.

\begin{tabular}{|c|c|c|c|c|c|}
\hline \multirow[t]{2}{*}{ Specimen } & \multirow[t]{2}{*}{ Description } & \multicolumn{2}{|c|}{ Deflection at first crack $(\mathrm{mm})$} & \multicolumn{2}{|c|}{ Deflection at ullimaste losd $(\mathrm{mm})$} \\
\hline & & Idgedial gauge & $\begin{array}{c}\text { Mid-span dial } \\
\text { gauge (-)* }\end{array}$ & Idge dial gauge & $\begin{array}{c}\text { Mid-span dia } \\
\text { gauge }(-)^{4}\end{array}$ \\
\hline C & Non-Monolithically & 0.45 & 0.43 & 1.10 & 1.60 \\
\hline C1 & Monolithically & 0.40 & 1.90 & 1.47 & 4.38 \\
\hline$C 2$ & $0.5 \%$ steel fiber & 0.85 & 0.85 & 2.05 & 3.85 \\
\hline C3 & $1 \%$ steel fiber & 0.27 & 0.81 & 1.24 & 3.99 \\
\hline
\end{tabular}

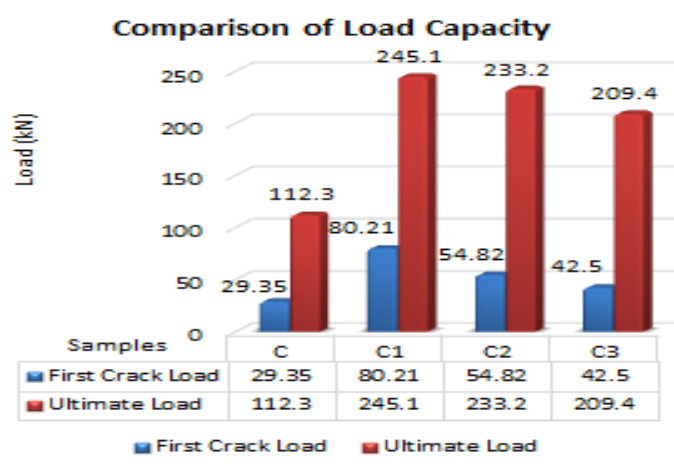

Figure 10: Comparison of Load Carrying Capacity 


\section{Conclusions}

- It is clearly obvious that the monolithic beam-column joint without steel fiber was more efficient than the non-monolithically cast frame. The ultimate load for frame monolithic increases more than the nonmonolithic frame by about $54 \%$.the part of beam-column joint casted nonmonolithically caused a poor interaction section, splitting zone occur at the beam column joint area. Figure 8.

- The effect of adding steel fibers to the beam-column joint of (0.5) \% and (1) \% increases the load capacity and loaddisplacement, for general. The increase the percentage of steel fibers causes improvement in load-deflection curve and behavior of cracks pattern. The ultimate loads for beam-column joint of $1 \%$ steel fibers increased when adding $0.5 \%$ steel fibers by about (4.5) \%. Figure 9.

- The frame cast monolithically indicates by larger amount of ultimate load when the steel fibers were added as $(0.5) \%$ to the mix about (14.7) \%, and less for the frame with steel fiber (1) \% about (4.8) \%. Figure 7.

- The load-deflection relationship indicates that the frame cast monolithically shows strength development better than the frame cast non-monolithically, both parts in dial gauge places, at the center of mid span and the edge of cantilever, figure $(11, \mathrm{a}, \mathrm{b}$.). The frame of steel fibers has $1 \%$ more resistance in load applied on frame and shows higher ultimate load than the frame of $0.5 \%$ steel fibers. The loaddisplacement for frame $0.5 \%$ steel fibers in process of applying load was developed more than the frame with $(1 \%)$. Figure 11.a.

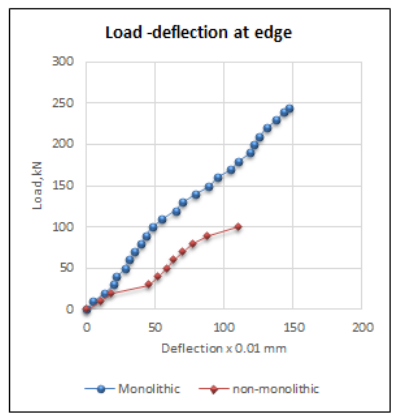

a- Edgedial Gauge

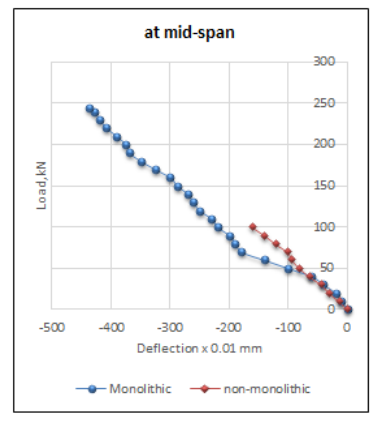

b- Mid-span dial Gauge
Figure 11: Load - Deflection Relationship for Frame (C) \& (C1)

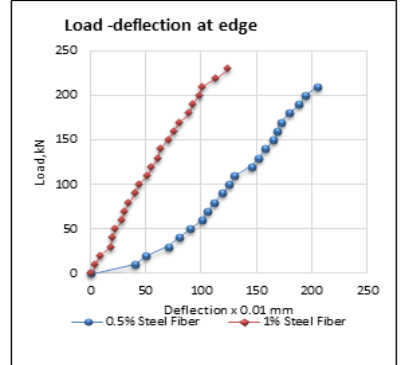

a- Edge dial Gauge

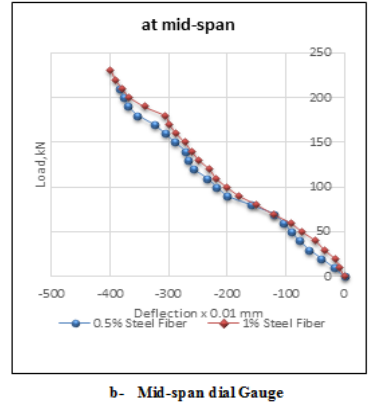

Figure 12: Load - Deflection Relationship for Frame (C2) \& (C3)

References

[1]. Vijayalakshmi, N. Kalaivani, M. and Murugesan. A., Experimental investigation of RC- Beam column joint strengthening by FPP Warping, international journal of civil and structural engineering, 1,(1), (2010).

[2]. GENCOGLU Mustafa, EREN Ilhan, An Experimental Study on the Effect of Steel Fiber Reinforced Concrete on the Behavior of the Exterior Beam-Column Joints Subjected to Reversal Cyclic Loading, Turkish J. Eng. Env. Sci., 493 502. TUBITAK, 2002.

[3]. Wang. Yung-Chih , and Lee. Ming-Gin , Ultra-high Strength Steel Fiber Reinforced Concrete for Strengthening Of RC Frames, Journal of Marine Science and Technology, 15, (3), (2007), 210-218.

[4]. Gao, J., Sun, W. and Morino, K., Mechanical Properties of Steel FiberReinforced, High-Strength, Lightweight Concrete, Cement and Concrete Composites Journal, 19, (4), (1997), 307313.

[5]. Lo, T.Y., Tang, W.C. and Cui, H.Z., The Effects of Aggregate Properties on Lightweight Concrete, Building and Environment Journal, 42, (8), (2007), 3025-3029.

[6]. ACI Committee (213R-2003), Guide for Structural Lightweight-Aggregate Concrete, American Concrete Institute, September, 2003.

[7]. Iraqi Standard Specification (IQS), No.5/1984, Portland Cement, Central Organization for Standardization \& Quality Control (COSQC), Baghdad, Iraq, 1984.

[8]. Iraqi Standard Specification (IQS), No.45/1984, Aggregates from Natural Sources for Concrete and Construction, Central Organization for Standardization \& Quality Control (COSQC), Baghdad, Iraq, 1984.

[9]. ASTM C39-2003, Test Method for Compressive Strength of Cylindrical Concrete Specimens, ASTM International, 2003. 
[10]. B.S.1881, part116, Method for Determination of Compressive Strength of Concrete Cubes, British Standard Institution, 1881.

[11]. ASTM C469-2003 a, Test Method for Static Modulus of Elasticity and Poisson's Ratio of Concrete in Compression, ASTM International, 2003.

[12]. ACI (318M-2014), Building Code Requirements for Structural Concrete and Commentary, American Concrete Institute, September, 2014.

[13]. ACI Code Committee (209.2R-2008), 2008, Guide for Modeling and Calculating Shrinkage and Creep in Hardened Concrete, American Concrete Institute, May, 2008. 